\title{
Resistance to Grapevine leafroll associated virus-2 is conferred by post-transcriptional gene silencing in transgenic Nicotiana benthamiana
}

\author{
Kai-Shu Ling $\cdot$ Hai-Ying Zhu $\cdot$ Dennis Gonsalves
}

Received: 22 December 2006/ Accepted: 18 September 2007/Published online: 3 October 2007

(C) Springer Science+Business Media B.V. 2007

\begin{abstract}
Grapevine leafroll-associated virus-2 (GLRaV-2) is an important component of the leafroll disease complex in grapevine. We have previously sequenced the GLRaV-2 genome and identified the coat protein (CP) gene. The objective of this study is to test the concept of pathogen-derived resistance against a closterovirus associated with grapevine leafroll disease. Because GLRaV-2 is capable of infecting Nicotiana benthamiana, we decided to test the concept on this herbaceous host. Thirty-seven $\mathrm{T}_{0}$ transgenic $N$. benthamiana plants expressing the GLRaV-2 CP gene were regenerated following Agrobacterium-mediated transformation. Disease resistance was evaluated in greenhouse-grown $T_{1}$
\end{abstract}

The U.S. Government's right to retain a non-exclusive, royaltyfree license in and to any copyright is acknowledged.

K.-S. Ling · H.-Y. Zhu · D. Gonsalves

Department of Plant Pathology, NYSAES,

Cornell University, Geneva, NY 14456, USA

K.-S. Ling ( ()

USDA-ARS, US Vegetable Laboratory, 2700 Savannah

Highway, Charleston, SC 29414, USA

e-mail: kai.ling@ars.usda.gov

\section{H.-Y. Zhu}

Department of Laboratory Medicine, University

of Washington, Seattle, WA 98195, USA

D. Gonsalves

USDA-ARS, Pacific Basin Agricultural Research Center, 99 Aupuni St., Suite 204, Hilo, HI 96720, USA and $\mathrm{T}_{2}$ plants by mechanical inoculation with GLRaV-2. Although all the inoculated non-transgenic plants showed symptoms 2-4 weeks post inoculation, various numbers of transgenic plants (16-100\%) in 14 of $20 \mathrm{~T}_{1}$ lines tested were not infected. In these resistant plants, GLRaV-2 was not detectable by enzyme linked immunosorbent assay. Although virus resistance was confirmed in $\mathrm{T}_{2}$ progenies, the percentage of resistant plants was generally lower $(0-63 \%)$ than that of the corresponding $\mathrm{T}_{1}$ lines $(0-$ $100 \%)$. Northern blot and nuclear run-off results showed that virus resistance in the transgenic plants was consistently associated with the low level of transgene RNA transcript suggesting a post-transcriptional gene silencing. The success of pathogenderived resistance to GLRaV-2 in transgenic $N$. benthamiana plants represents the first step towards eventual control of the leafroll disease in grapevines using this strategy.

Keywords Closteroviridae - Coat protein . Pathogen derived resistance - Grapevine · Vitis vinifera

\section{Introduction}

Leafroll is an important viral disease of grapevines worldwide. The disease affects both grape yield and its sugar content, thereby altering wine quality. Etiological studies on the leafroll disease complex 
are complicated by the fact that a total of nine serologically distinct viruses in the family Closteroviridae are associated with the disease (Alkowni et al. 2004; Fauquet et al. 2005). One major virus component in this disease complex is Grapevine leafroll associated virus-2 (GLRaV-2), a species of genus Closterovirus, family Closteroviridae. With $16,493 \mathrm{nt}$ in its genome, GLRaV-2 is composed of nine open reading frames (ORF) organized in a typical closterovirus arrangement (Dolja et al. 1994; Zhu et al. 1998; Meng et al. 2005). The coat protein (CP) gene is encoded at the $3^{\prime}$ terminal portion of the genome and is likely expressed via a subgenomic RNA (Zhu et al. 1998).

Since the first report that transgenic tobacco plants expressing the CP gene of Tobacco mosaic virus (TMV) confer resistance to TMV infection (PowellAbel et al. 1986), there have been numerous examples on the successful application of the concept of pathogen-derived resistance (PDR) against different types of plant viruses (Prins 2003; Tenllado et al. 2004). However, success in using the PDR strategy to confer resistance to closteroviruses has been limited. Much of its progress is concentrated with Citrus tristeza virus (CTV) (Batuman et al. 2006; Fagoaga et al. 2006).

Although grapevine transformation with virusderived sequences has been successful (Krastanova et al. 1995; Mauro et al. 1995; Xue et al. 1999; Golles et al. 2000; Radian-Sale et al. 2000; Spielmann et al. 2000; Gambino et al. 2005; Maghuly et al. 2006), testing virus resistance in grapevine is complicated by the lack of efficient mechanical or vector transmission. Evaluation of virus resistance by symptom expression in grapevine would take years to complete. GLRaV-2 is the only one of nine grapevine leafroll associated viruses that is capable of infecting an herbaceous host, Nicotiana benthamiana (Goszczynski et al. 1996). The objective of this study is to test the concept of pathogenderived resistance against a closterovirus associated with grapevine leafroll disease in $N$. benthamiana. Here we describe the development of transgenic $N$. benthamiana plants expressing the GLRaV-2 CP gene and evaluation of transgenic plants against GLRaV-2 infection. We report that resistance to GLRaV-2 in transgenic $N$. benthamiana is via the mechanism of post-transcriptional gene silencing (PTGS).

\section{Methods, results and discussion}

Double-stranded RNA (dsRNA) purified from GLRaV-2 (isolate PN) infected grapevine tissue (Zhu et al. 1998) was used as template for CP gene amplification. The complete CP gene plus $56 \mathrm{nt}$ downstream region was amplified by reverse transcription-polymerase chain reaction (RT-PCR) with primers CP-96F (cggaattcaccATGGAGTTGATGTCCGACAG, nt positions 13,084-13,103), and CP-96R (agcggatccatggCAGATTCGTGCGTAGCAGTA at nt 13,714-13,733). An Nco I restriction site was introduced at the beginning of each primer (underlined) to facilitate the cloning process. The RT-PCR amplified product was purified from a low melting temperature agarose gel, digested with Nco I, and cloned into plant expression vector pEPT8 (Ling et al. 1997). The sequence and orientation of the recombinant $\mathrm{CP}$ gene were then confirmed by enzyme restriction analysis and sequencing (data not shown). The resulting expression-cassette, which consisted of a double enhanced (Enh) Cauliflower mosaic virus (CaMV) 35S-promoter (35S-P), $5^{\prime}$ untranslated leader of Alfalfa mosaic virus RNA4 (AMV 5'UT), CP gene of GLRaV-2 (GLRaV-2 CP) and $3^{\prime}$ terminal untranslated sequence of CaMV 35S (35S-T), was digested with Hind III, isolated from a low melting point temperature agarose gel and cloned into Hind III restricted binary vector pGA482GG (Quemada et al. 1991). The resulting binary vector, pGA482GG/ EPT8CP-GLRaV2, was transformed by electroporation into Agrobacterium tumefaciens strain LBA4404. Agrobacterium-mediated transformation and regeneration of transgenic $N$. benthamiana plants were performed essentially as described by Horsch et al. (1985).

Upon Agrobacterium-mediated transformation, 37 kanamycin resistant $N$. benthamiana plants with positive reaction for neomycin phosphotransferase II (NPTII) protein ( $5^{\prime}$ Prime to $3^{\prime}$ Prime, Inc. Boulder, $\mathrm{CO})$ were considered transgenics. Five other plants with negative NPTII reaction were regarded as nontransgenics. Presence of $\mathrm{CP}$ gene of GLRaV-2 $(663 \mathrm{bp})$ in transgenic plants was confirmed by PCR with GLRaV-2 specific primers (CP-96F and CP-96R) (data not shown). CP expression in transgenic plants was analyzed by indirect ELISA with the antibody prepared against a recombinant $\mathrm{CP}$ of GLRaV-2 (Ling et al. 2007). Results showed that 
transgenic $\mathrm{CP}$ expression in $\mathrm{T}_{0}$ transgenic plants was extremely low to non-detectable (OD405 nm: 0.120.13), similar to that of a non-transgenic healthy control (OD405 nm: 0.12). Although Western blot detected the expected $22 \mathrm{kDa} \mathrm{CP}$ in GLRaV-2 infected samples, such product was not detectable in transgenic plants (data not shown). Nevertheless, $\mathrm{T}_{0}$ plants were self-pollinated in greenhouse. Resistance screening experiments were conducted with $\mathrm{T}_{1}$ and $\mathrm{T}_{2}$ seedlings, respectively.

Prior to being tested for resistance, $\mathrm{T}_{1}$ seedlings from 20 transgenic lines were screened for NPT II protein to identify transgenic from non-transgenic plants. The isolate $94 / 970$ of $\mathrm{GLRaV}-2$, which was originally identified and transmitted from grapevine to $N$. benthamiana in South Africa (Goszczynski et al. 1996), was used as inoculum. CP gene sequence of the isolate 94/970 was identical to that of the PN isolate used in vector construction (Meng et al. 2005). At the six to seven leaf stage, two developed lower leaves were collected and saved at $-80^{\circ} \mathrm{C}$ for further laboratory analyses. Two youngest leaves were challenge inoculated with GLRaV-2 isolate 94/ 970. Inoculum was prepared by grinding $1 \mathrm{~g}$ of GLRaV-2 infected $N$. benthamiana leaf tissue in $5 \mathrm{ml}$ of $0.01 \mathrm{M}$ phosphate buffer ( $\mathrm{pH}$ 7.0). Test plants were lightly dusted with Carborundum and rubbed gently with the prepared virus inoculum. Non-transformed $N$. benthamiana plants were included as controls in all screening experiments. The inoculated plants were maintained under greenhouse conditions and observed for symptom development every other day for at least 60 days. Upon infection with GLRaV2, all nontransgenic control plants produced chlorotic, and occasionally necrotic lesions followed by systemic vein clearing and necrosis. Eventually, GLRaV-2 infected susceptible plants died.

Responses of the transgenic plants to GLRaV-2 infection could be grouped into three types: (1) resistant, the tested plants remained asymptomatic throughout the test; (2) tolerant, delay and attenuation in disease symptom expression; (3) susceptible, typical symptoms observed 2-4 weeks post inoculation (wpi). In the first screening experiment, resistant plants were obtained in $\mathrm{T}_{1}$ progenies from 14 of 20 lines tested (Fig. 1a, Table 1). The percentage of resistant plants in these 14 putative resistant lines varied widely, ranging from $100 \%$ in line 19 to $16 \%$ in line 8 . When tested by indirect ELISA, the resistant plants were shown to have no apparent virus accumulation. Six other lines did not produce any resistant plants, and $93-100 \%$ of the progeny was susceptible (Table 1). Plants rated as susceptible showed severe symptoms (Fig. 1a) and eventually died within 3-8 wpi.

In a separate experiment, additional $\mathrm{T}_{1}$ progenies were tested for four transgenic lines that produced variable number of resistant plants (lines 1, 4, 5, and 19), and two lines that produced only susceptible plants (lines 12 and 13) (Table 1). $\mathrm{T}_{1}$ progenies from three of the lines (1, 4, and 19) produced again resistant plants although at a lower percent (range $23-42 \%$ ) than that in the first screening (range 23$100 \%$ ). Although $43 \%$ of $\mathrm{T}_{1}$ plants in line 5 were considered resistance in the first screening, none of the tested plants were resistant in the second test. As expected, progenies from the two susceptible lines (12 and 13) remained susceptible.

To validate these results, additional screening was done with $T_{2}$ plants derived from selfing of three $T_{1}$ lines (1, 4 and 19). In the first screening experiment, we tested plants generated from five $\mathrm{T}_{2}$ progenies for line 1 (designated as $1-22,1-30,1-31,1-35$, and 141 ), four $\mathrm{T}_{2}$ progenies for line 4 (4-139, 4-149, 4152 , and 4-174), and four $\mathrm{T}_{2}$ progenies for line 19 (19-650, 19-657, 19-659, and 19-660). In the second test with $\mathrm{T}_{2}$ progenies, additional plants derived from these same resistant lines were used. Interestingly, greater variability in plant response to virus infection was observed in the $T_{2}$ progenies (Table 2). In general, the percentage of resistant plants in the $T_{2}$ progenies was lower than that of the corresponding $\mathrm{T}_{1}$ plants (Table 1): for line 1, $0-57 \%$ in the $\mathrm{T}_{2}$ vs. $42-56 \%$ in the $\mathrm{T}_{1}$; for line $4,0-50 \%$ in the $\mathrm{T}_{2}$ vs. $33-71 \%$ in the $\mathrm{T}_{1}$; and for line $19,0-63 \%$ in the $\mathrm{T}_{2}$ vs. $23-100 \%$ in the $\mathrm{T}_{1}$. Resistant plants remained asymptomatic throughout the test and were able to develop to normal maturity (Fig. 1).

To evaluate whether the mechanism of PTGS was involved in conferring transgenic $N$. benthamiana plant resistance to GLRaV-2, Northern blot and nuclear run-off transcription experiments were performed on the selected resistant and susceptible plants. Total RNA was extracted from collected leaf tissues following the method described by Napoli et al. (1990). About $10 \mu \mathrm{g}$ of total RNA per well was electrophoresed on a denatured agarose gel. After electrophoresis, the gel was stained with ethidium 


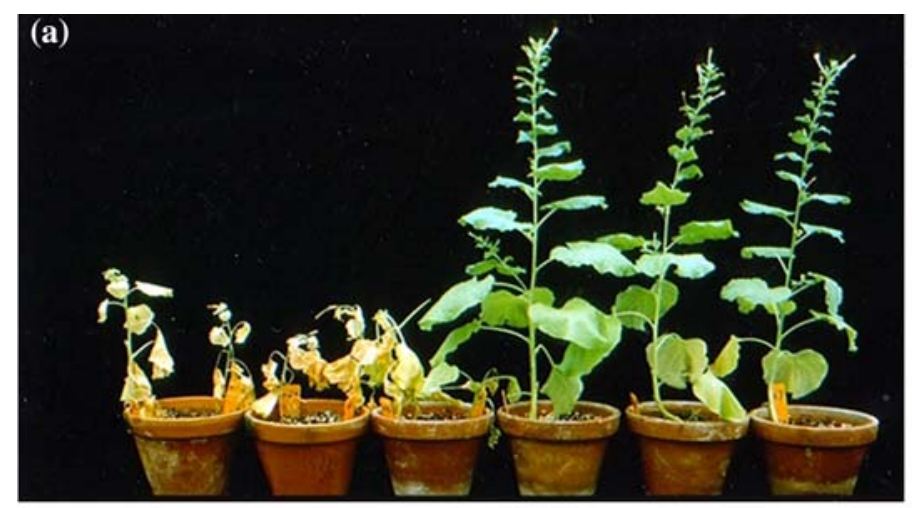

(b)

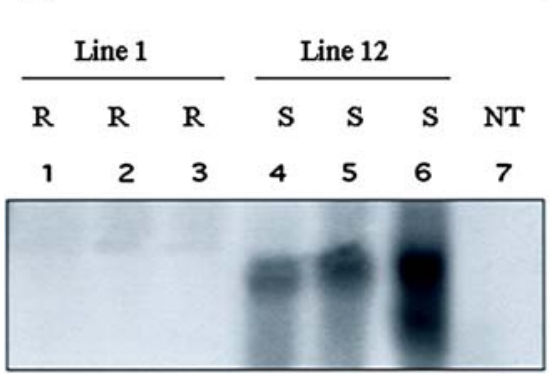

(c) $N T \quad R \quad S \quad R$

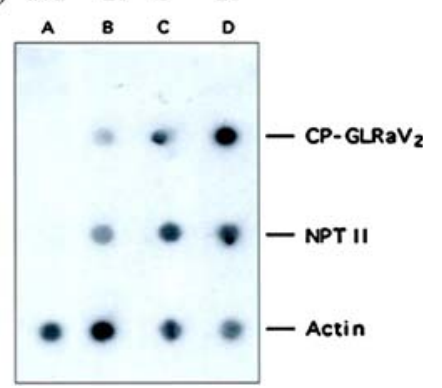

Fig. 1 Responses of transgenic Nicotiana benthamiana plants to GLRaV-2 infection, and analyses of transgenic plants by Northern blot and nuclear run-off transcription. (a) Severe disease symptoms (dying plants) developed on non-transgenic plants (the left 3 potted plants). The resistant response in $\mathrm{T}_{2}$ transgenic plants (line 1-22) was asymptomatic (the right 3 potted plants). (b) Northern blot analysis, lanes 1-3: three

bromide to reveal a relative similar amount of ribosomal RNA for each sample (data not shown). The conditions for Northern blot hybridization were those recommended by the manufacturer (DuPont NEN, Boston, MA). The probe used was a PCR amplified GLRaV-2 CP gene product, randomly labeled with ${ }^{32} \mathrm{P}(\alpha$-dATP) using the Klenow fragment of DNA polymerase I (Feinberg and Vogelstein 1983). Results in Northern blot analyses showed that while resistant $T_{1}$ plants (line 1 ) had low to nondetectable level of steady state transgene RNA transcript, higher accumulation was observed in the susceptible plants (line 12) (Fig. 1b). Isolation of nuclei and nuclear run-off transcription assays were performed essentially as described (Pang et al. 1996). The same amount of labeled nascent RNA was hybridized to dot blot membranes that contained $0.2 \mu \mathrm{g}$ of CP-GLRaV-2, Actin, or NPT II genes respectively. Results in nuclear run-off experiments resistant $\mathrm{T}_{1}$ plants from line 1; lanes 4-6: three susceptible $\mathrm{T}_{1}$ plants from line 12; and lane 7: non-transgenic plant. (c) Nuclear run-off transcription experiments, lane A: nontransgenic plant (NT); lane B: a resistant $\mathrm{T}_{1}$ plant in line 1 ; lane C: a susceptible $\mathrm{T}_{1}$ plant in line 12 ; lane $\mathrm{D}$ : a resistant $\mathrm{T}_{1}$ plant in line 19

showed that transgene RNA transcripts were actively transcribed from all tested transgenic plants, either from the resistant lines 1 and 19 or the susceptible line 12 (Fig. 1c). Some level of variability in the intensity of CP-gene was likely due to the handling variance among samples under this experiment, which was also evidenced in the controls (Actin and NPT II) (Fig. 1c). Taken together, these results showed that the reduced levels of steady-state transgene RNA transcripts in the GLRaV-2 resistant $N$. benthamiana plants were likely due to PTGS.

We have shown here that following introduction of the CP gene of GLRaV-2 into N. benthamiana, some of the transgenic plants were protected against GLRaV-2 infection via the mechanism of PTGS. Interestingly, not all the plants in a given transgenic line were resistant. The resistance was also variable from generation to generation. Our results in $N$. benthamiana suggest that development of 
Table 1 Evaluation of $T_{1}$ transgenic Nicotiana benthamiana lines for resistance to GLRV-2 infection

\begin{tabular}{|c|c|c|c|c|}
\hline \multicolumn{5}{|c|}{ First screening experiment } \\
\hline \multirow[t]{2}{*}{ Line \# } & \multirow[t]{2}{*}{$n^{\mathrm{a}}$} & \multicolumn{3}{|c|}{$\%$ showing reactions of } \\
\hline & & Susceptible ${ }^{b}$ & Tolerant $^{c}$ & Resistant $^{\mathrm{d}^{*}}$ \\
\hline 19 & 15 & 0 & 0 & 100 \\
\hline 17 & 12 & 0 & 8 & 92 \\
\hline 20 & 19 & 16 & 0 & 84 \\
\hline 21 & 14 & 7 & 21 & 72 \\
\hline 4 & 31 & 13 & 16 & 71 \\
\hline 2 & 36 & 19 & 17 & 64 \\
\hline 3 & 38 & 29 & 11 & 60 \\
\hline 1 & 39 & 36 & 8 & 56 \\
\hline 7 & 32 & 16 & 28 & 56 \\
\hline 6 & 36 & 12 & 44 & 44 \\
\hline 5 & 33 & 18 & 39 & 43 \\
\hline 9 & 36 & 25 & 33 & 42 \\
\hline 16 & 33 & 18 & 39 & 43 \\
\hline 8 & 37 & 60 & 24 & 16 \\
\hline 11 & 13 & 85 & 15 & 0 \\
\hline 10 & 14 & 93 & 7 & 0 \\
\hline 12 & 17 & 94 & 6 & 0 \\
\hline 15 & 32 & 94 & 6 & 0 \\
\hline 14 & 17 & 100 & 0 & 0 \\
\hline 13 & 14 & 100 & 0 & 0 \\
\hline Control $^{\mathrm{e}}$ & 15 & 100 & 0 & 0 \\
\hline \multicolumn{5}{|c|}{ Second screening experiment } \\
\hline 1 & 19 & 26 & 32 & 42 \\
\hline 4 & 15 & 60 & 7 & 33 \\
\hline 19 & 13 & 77 & 0 & 23 \\
\hline 5 & 17 & 82 & 18 & 0 \\
\hline 12 & 16 & 88 & 12 & 0 \\
\hline 13 & 18 & 72 & 28 & 0 \\
\hline Control $^{\mathrm{e}}$ & 24 & 96 & 4 & 0 \\
\hline
\end{tabular}

${ }^{a}$ Number of $T_{1}$ plants in each line tested

b Susceptible, typical symptoms were observed two to four weeks post inoculation

c Tolerant, symptom expression was delayed and attenuated

${ }^{d}$ Resistant, plants remained asymptomatic throughout the test

e Non-transgenic plant control

* The average percentage of resistant plants when combining the data obtained in the first and second screening experiments for $\mathrm{T}_{1}$ lines 1,4 , and 19 was 52, 59, and $64 \%$, respectively

transgenic virus resistance could be a practical way to control GLRaV-2 in grapevines, and that GLRaV-2 may be a good model system for investigating the
Table 2 Evaluation of $\mathrm{T}_{2}$ transgenic Nicotiana benthamiana lines for resistance to GLRaV-2 infection

\begin{tabular}{|c|c|c|c|c|}
\hline \multicolumn{5}{|c|}{ First screening experiment } \\
\hline \multirow[t]{2}{*}{ Line \# } & \multirow[t]{2}{*}{$N^{\mathrm{a}}$} & \multicolumn{3}{|c|}{$\%$ showing reactions of } \\
\hline & & Susceptible $^{b}$ & Tolerant $^{c}$ & Resistant $^{\mathrm{d}^{*}}$ \\
\hline $1-22$ & 12 & 25 & 25 & 50 \\
\hline $1-30$ & 8 & 50 & 25 & 25 \\
\hline $1-31$ & 10 & 50 & 30 & 20 \\
\hline $1-35$ & 10 & 40 & 60 & 0 \\
\hline $1-41$ & 7 & 14 & 29 & 57 \\
\hline $4-139$ & 11 & 36 & 36 & 28 \\
\hline $4-149$ & 7 & 14 & 72 & 14 \\
\hline $4-152$ & 8 & 100 & 0 & 0 \\
\hline $4-174$ & 8 & 50 & 0 & 50 \\
\hline $19-650$ & 10 & 70 & 10 & 20 \\
\hline $19-657$ & 12 & 50 & 17 & 33 \\
\hline $19-659$ & 8 & 12 & 25 & 63 \\
\hline $19-660$ & 8 & 13 & 74 & 13 \\
\hline Control $^{\mathrm{e}}$ & 12 & 100 & 0 & 0 \\
\hline \multicolumn{5}{|c|}{ Second screening experiment } \\
\hline $1-8$ & 10 & 70 & 20 & 10 \\
\hline $1-14$ & 11 & 55 & 27 & 18 \\
\hline $1-17$ & 12 & 58 & 17 & 25 \\
\hline $1-20$ & 14 & 50 & 29 & 21 \\
\hline $1-24$ & 13 & 92 & 0 & 8 \\
\hline $4-33$ & 12 & 50 & 42 & 8 \\
\hline $4-36$ & 14 & 57 & 14 & 29 \\
\hline $4-43$ & 14 & 93 & 7 & 0 \\
\hline $4-46$ & 14 & 58 & 27 & 15 \\
\hline $19-130$ & 13 & 68 & 25 & 17 \\
\hline $19-133$ & 14 & 100 & 0 & 0 \\
\hline $19-141$ & 11 & 73 & 18 & 9 \\
\hline Control $^{\mathrm{e}}$ & 13 & 100 & 0 & 0 \\
\hline
\end{tabular}

${ }^{\text {a }}$ Number of $\mathrm{T}_{2}$ plants in each line tested

b Susceptible, typical symptoms were observed 2-4 weeks post inoculation

c Tolerant, symptom expression was delayed and attenuated

${ }^{d}$ Resistant, plants remained asymptomatic throughout the test

e Non-transgenic plant control

* The range of resistant plants when combining the two screening experiments for three $\mathrm{T}_{2}$ lines tested varied as follows: line $1(0-57 \%)$, line $4(0-50 \%)$, and line $19(0-63 \%)$

factors affecting the variability of resistance to closteroviruses.

Reports on the use of PDR to develop resistance among closteroviruses have so far been limited to 
attempts with CTV (Dominguez et al. 2000, 2002; Febres et al. 2003; Batuman et al. 2006; Fagoaga et al. 2006). In general, results have shown that resistance to CTV in transgenic citrus plants is variable. The work on Mexican lime showed delayed symptom expression in plants transformed with the CP gene (Dominguez et al. 2002) and very strong resistance with plants expressing the p23 gene (Fagoaga et al. 2006). However, reactions among the transgenic lines were variable. For example different lines of p23 expressing transgenic citrus plants showed both resistant and susceptible reactions to CTV infection (Fagoaga et al. 2005 and Fagoaga et al. 2006). In another work, transgenic plants expressing p23 and the $3^{\prime}$ UTR sequence provided resistance to CTV in $N$. benthamiana but not in citrus (Batuman et al. 2006). These results with CTV actually show similarities with our work on GLRaV-2 in that the number of resistant plants obtained for a given transgenic line was variable and in general the percentage of resistant plants were lower in the $T_{2}$ than the $T_{1}$ generation.

Overall, the results obtained so far for CTV and for GLRaV-2 show that the inheritance of closterovirusderived resistance is variable and the level of resistance is less than those obtained for other viral groups, such as potyviruses (Batuman et al. 2006; Fagoaga et al. 2006; Tenllado et al. 2004). Perhaps, reason for the difficulty in generating PDR resistance to CTV in citrus and now GLRaV-2 in N. benthamiana may be due to the existence of three distinctive RNA silencing suppressors in these large RNA genomes ( $\sim 20 \mathrm{~kb})$ (Lu et al. 2004). Interestingly, the three RNA silencing suppressors in CTV have three different functions: p23 targeting the intracellular space, CP the intercellular, and p20 both levels (Lu et al. 2004). Furthermore, the strength and number of silencing suppressors in the genome of closteroviruses may accentuate the effects of other factors such as plant age, gene dosage, and environmental conditions (Pang et al. 1996). The latter may account for the differences in level of resistance even among clones taken from a parent plant that showed immunity (Fagoaga et al. 2005; Fagoaga et al. 2006). Because GLRaV-2 is easily transmissible and induces severe symptoms in $N$. benthamiana (Goszczynski et al. 1996), it may serve as a good model for systematically examining the effect of silencing suppressors in closteroviruses.
Grapevine leafroll viruses and CTV, for example, cause much damage to two of the most widely grown fruit crops, grape and citrus. Transformation of grapevines has been achieved and in fact transgenic grapevines with the current GLRaV-2 CP construct were produced (Xue et al. 1999; Krastanova et al. 2000). Unfortunately, evaluation of virus resistance in these plants has been delayed. Nevertheless, the potential benefits in developing multiple virus resistance in grapevines against closteroviruses through genetic engineering might be significant since at least nine different viruses in the family of Closteroviridae are implicated as the causal agents of grapevine leafroll disease (Alkowni et al. 2004; Fauquet et al. 2005). Recent work has demonstrated that linking segments of genes from different viruses could induce multiple virus resistance (Bucher et al. 2006; Jan et al. 2000). Although silencing suppressors have yet to be identified in any of the closteroviruses that are associated with the grapevine leafroll disease, it is tempting to speculate that multiple silencing suppressors may also be involved in these virus genomes, including GLRaV-2. To be successful in developing virus resistance through PDR strategy, the new generation of gene construct design needs to fully consider the involvement of multiple gene silencing suppressors in these viruses. Nevertheless, the success in the present study in transgenic $N$. benthamiana plants against GLRaV-2 may represent the first step towards an eventual control of the leafroll disease in grapevines.

Acknowledgments We thank Drs. S.-Z. Pang, B. Meng, A. Levi, and W. P. Wechter for their critical reviews to the manuscript and Dr. Dariusz Goszczynski for providing a culture of GLRaV-2, isolate 94/970. This research was supported in part by USDA/ARS Cooperative agreement no. 58-2349-9-01 with the USDA Clonal Repository at Geneva, New York.

\section{References}

Alkowni R, Rowhani A, Daubert S, Golino D (2004) Partial characterization of a new Ampelovirus associated with grapevine leafroll disease. J Plant Pathol 86:123-133

Batuman O, Mawassi M, Bar-Joseph M (2006) Transgene consisting of a dsRNA of an RNAi suppressor plus the $3^{\prime}$ UTR provide resistance to Citrus tristeza virus sequences in Nicotiana benthamiana but not in citrus. Virus Genes 33:319-327

Bucher E, Lohuis D, van Poppel PMJA, Geerts-Dimitriadou C, Goldbach R, Prins M (2006) Multiple virus resistance at a 
high frequency using a single transgene construct. J Gen Virol 87:3697-3701

Dolja VV, Karasev AV, Koonin EV (1994) Molecular biology and evolution of closteroviruses: sophisticated build-up of large RNA genomes. Annu Rev Phytopathol 32:261-285

Dominguez A, Guerri J, Cambra M, Navarro L, Moreno P, Pena L (2000) Efficient production of transgenic citrus plants expressing the coat protein gene of Citrus tristeza virus. Plant Cell Rep 19:427-433

Dominguez A, Hermoso de Mendoza A, Guerri J, Cambra M, Navarro L, Moreno P, Pena L (2002) Pathogen-derived resistance to Citrus tristeza virus (CTV) in transgenic Mexican lime (Citrus aurantifolia (Christ.) Swing.) plants expressing its $p 25$ coat protein gene. Mol Breed 10:1-10

Fagoaga C, Lopez C, Moreno P, Navarro L, Flores R, Pena L (2005) Viral-like symptoms induced by the ectopic expression of the p23 gene of Citrus tristeza virus are citrus specific and do not correlate with the pathogenicity of the virus strain. Mol Plant Microbe Interact 18:435-445

Fagoaga C, Lopez C, Hermoso de Mendoza A, Moreno P, Navarro L, Flores R, Pena L (2006) Post-transcriptional gene silencing of the p23 silencing suppressor of Citrus tristeza virus confers resistance to the virus in transgenic Mexican lime. Plant Mol Biol 60:153-165

Fauquet CM, Mayo MA, Maniloff J, Desselberger U, Ball LA (2005) Virus taxonomy, eighth report of the International Committee on Taxonomy of Viruses. Academic Press, Elsevier, London, $1162 \mathrm{pp}$

Febres VJ, Niblett CL, Lee RF, Moore GA (2003) Characterization of grapefruit plants (Citrus paradise Macf.) transformed with Citrus tristeza closterovirus genes. Plant Cell Rep 21:421-428

Feinberg AP, Vogelstein B (1983) A technique for radiolabeling DNA restriction endonuclease fragments to high specific activity. Anal Biochem 132:6-13

Gambino G, Gribaudo I, Leopold S, Schartl A, Laimer M (2005) Molecular characterization of grapevine plants transformed with GFLV resistance genes. I. Plant Cell Rep 24:655-662

Golles R, Moser R, Puhringer H, Katinger H, Leimer da Camara Machado M, Minafra A, Savino V, Saldarelli P, Martelli GP, Camara Machao A (2000) Transgenic grapevines expressing coat protein gene sequences of Grapevine fanleaf virus, Arabis mosaic virus, Grapevine virus $A$ and Grapevine virus B. Acta Hortic 528:305-311

Goszczynski DE, Kasdorf GGF, Pietersen G, van Tonder H (1996) Detection of two strains of Grapevine leafrollassociated virus 2. Vitis 35:133-135

Horsch RB, Fry JE, Hoffman NL, Eichholtz D, Rogers SG, Fraley RT (1985) A simple and general method for transferring genes into plants. Science 277:1229-1231

Jan FJ, Fagoaga C, Pang SZ, Gonsalves D (2000) A single chimeric transgene derived from two distinct viruses coffers multi-virus resistance in transgenic plants through homology-dependent gene silencing. J Gen Virol 81:2103-2109

Krastanova S, Perrin M, Barbier P, Demangeat G, Cornuet P, Bardonnet N, Otten L, Pinck L, Walter B (1995) Transformation of grapevine rootstocks with the coat protein gene of Grapevine fanleaf nepovirus. Plant Cell Rep $14: 550-554$
Krastanova S, Ling KS, Zhu HY, Xue B, Burr TJ, Gonsalves D (2000) Development of transgenic grapevine rootstocks with genes from Grapevine fanleaf virus and Grapevine leafroll associated closteroviruses 2 and 3. Acta Hortic 528:367-372

Ling KS, Zhu HY, Alvizo H, Hu JS, Drong RF, Slightom JL, Gonsalves D (1997) The coat protein gene of Grapevine leafroll associated closterovirus-3: cloning, nucleotide sequencing and expression in transgenic plants. Arch Virol 142:1101-1116

Ling KS, Zhu HY, Petrovic N, Gonsalves D (2007) Serological detection of Grapevine leafroll associated virus -2 using an antiserum developed against the recombinant coat protein. J Phytopathol 155:65-69

Lu R, Folimonov A, Shintaku M, Li WX, Falk BW, Dawson WO, Ding SW (2004) Three distinct suppressors of RNA silencing encoded by a $20-\mathrm{kb}$ viral RNA genome. Proc Natl Acad Sci USA 101:15742-15747

Maghuly F, Leopold S, Machado AC, Fernadez EB, Khan MA, Gambino G, Gribaudo I, Schartl A, Laimer MA (2006) Molecular characterization of grapevine plants transformed with GFLV resistance genes: II. Plant Cell Rep 25:546-553

Mauro MC, Tortain S, Walter B, Pinck L, Otten L, CoutosThevento P, Deloire A, Barbier P (1995) High efficiency regeneration of grapevine plants transformed with the GFLV coat protein gene. Plant Sci 112:97-106

Meng B, Li C, Goszczynski DE, Gonsalves D (2005) Genome sequences and structures of two biologically distinct strains of Grapevine leafroll-associated virus-2 and sequence analysis. Virus Genes 31:31-41

Napoli C, Lemieux C, Jorgensen R (1990) Introduction of a chimeric chalcone synthase gene into petunia results in reversible co-suppression of homologous genes in trans. Plant Cell 2:279-290

Pang SZ, Jan FJ, Carney K, Stout J, Tricoli DM, Quemada HD, Gonsalves D (1996) Post-transcriptional transgene silencing and consequent Tospovirus resistance in transgenic lettuce are affected by transgene dosage and plant development. Plant J 9:899-909

Powell-Abel P, Nelson RS, De B, Hoffmann N, Rogers SG, Fraley RT, Beachy RN (1986) Delay of disease development in transgenic plants that express the Tobacco mosaic virus coat protein gene. Science 232: 738-743

Prins M (2003) Broad virus resistance in transgenic plants. Trend Biotechnol 21:373-375

Quemada HD, Gonsalves D, Slightom JL (1991) Expression of coat protein gene from Cucumber mosaic virus strain $\mathrm{C}$ in tobacco: protection against infections by CMV strains transmitted mechanically or by aphids. Phytopathology 81:794-802

Radian-Sale S, Perl A, Edelbaum O, Kuznetsoza L, Gafny R, Sela I, Tanne E (2000) Transgenic Nicotiana benthamiana and grapevine plants transformed with Grapevine virus A (GVA) sequences. Phytoparasitica 28:1-8

Spielmann A, Krastanova S, Douet-Orhart V, Gugerli P (2000) Analysis of transgenic grapevine (Vitis rupestris) and Nicotiana benthamiana plants expressing an Arabis mosaic virus coat protein gene. Plant Sci 156:235-244 
Tenllado F, Llave C, Diaz-Ruiz JR (2004) RNA interference as a new biotechnological tool for the control of virus disease in plants. Virus Res 102:85-96

Xue BD, Ling KS, Reid CL, Krastanova SV, Sekiya ME, Momol EA, Sule S, Mozsar J, Gonsalves D, Burr TJ (1999) Transformation of five grape rootstocks with plant virus genes and a virE2 gene from Agrobacterium tumefaciens. In Vitro Cell Dev Biol-Plant 35:226-231
Zhu HY, Ling KS, Goszczynski D, McFerson JR, Gonsalves D (1998) Nucleotide sequence and genome organization of Grapevine leafroll-associated virus- 2 are similar to Beet yellows virus, the Closterovirus type member. J Gen Virol 79:1289-1298 